\title{
Article
}

\section{Commodifying Intimacy in 'Hard Times' A Hardcore Ethnography of a Luxury Brothel}

\author{
Daniel Briggs \\ Universidad Europea
}

\begin{abstract}
This paper is a methodological reflection on an ongoing covert ethnography I have been undertaking in a luxury brothel in Madrid, Spain. By accident, this study became a research project when I was employed by the manager to review porn forums offering feedback on the women that worked there and taught English to him. For 18 months now, I have worked in the brothel a couple of nights a week doing these duties and have come to know the manager's closest friends and family, the women who work there and the security staff. The context for the work is the expansion of the sex industry in an era of consumer society and selfgratification coupled with austerity politics which has disproportionately affected the opportunities for women in the formal labour market thus catapulting many into precarious situations in which selling sex becomes an option. This has crudely mixed with cultural change in Spain in the wake of increased neoliberal economics which have hollowed out notions of family, tradition and intimacy.
\end{abstract}

Keywords prostitution, brothel, covert ethnography, socio-economic bondage, commercial bondage

I drive twelve kilometres to a rich neighbourhood outside of Madrid; park up the road from the busy venue. I walk past the cordoned roads and the horses being groomed outside, amble into the complex past a guard and a car barrier and see stables, nice cars, and lots of rich people in Polo shirts and branded clothing. It is a different world.

I continue to walk into this high life of Spanish society, past mobile shops selling horse commodities and fashion items, and into the Sports Café. Inside, children are monitored by mums while dads make important calls and fiddle around on mobile phones and laptops. At the bar, I wait and drink a coffee as in front of me push four ten-year old girls and each get out iPhones. I see no point in jostling but my jaw drops when they take €50 notes out of their pockets.

Some minutes later, Guillermo walks in, sweaty and tired. Outside is his wife, dressed, unsurprisingly, in designer clothing, smoking a cigarette and talking loudly on the phone; she impatiently side steps and tosses her bleach blond hair from side to side like the horses do with their tails. A thin girl with a long ponytail dressed in white jodhpurs and brown boots stands next to her. It is Guillermo's daughter Elena. She speaks good English as I shake her hand. 'So you are Mr English?' she says 'I have been looking forward to meeting you.'

We hang around, not really knowing what to do because as soon as Guillermo's wife finishes a call she starts another one. Guillermo just cannot get her attention. Eventually, he leaves her and walks up to the stables to see his other daughter and their horses. We walk over the small piles of

DOI: http://dx.doi.org/10.5617/jea.5621

Journal of Extreme Anthropology; Vol. 2, No. 1: 66-88, ISSN: 2535-3241 
horse shit and head towards the well-kept stables in the corner of the arena. We walk to the end passing other horses which poke their heads out until we come to Guillermo's three horses and two ponies. The stables are well kept and outside each a young rider has his chair with his name and a curtain with the name of the horse. I meet his other daughter, a slightly taller twin. Her name is Maria. They are both 13 years old. As she strokes the horse, worth around €100,000, I meet the pony which is 19 years old and a former national champion too.

Guillermo and I walk back to the café and sit in the sun with his wife and her friend, Francesca, who is married to a rich man owning several yachts in Marbella. All around us, rich people sit and laugh as they drink beers and order tapas. Guillermo and I sit there a bit awkwardly at first as they don't speak English yet we continue our broken conversation about the horse competition. This is, after all, the national championship and the circuit is one of the hardest in Spain.

The weather continues to be hot and Guillermo gets a headache. As we move to the shade, the horse trainer, Mariano, comes over; he is a tall figure from Murcia with a shaved head and sunglasses. He sits behind us and tries to listen to the conversation and join in but his English is too poor. Somehow we get on to talk about women at which point Guillermo sees a side funny to his own jokes about having sex with other women. Mariano joins in and laughs before Guillermo complements him on his young girlfriend (who is only 20 and he is 34) before Mariano says that she is angry with him. There is an awkward moment when they seem to concur that the best way to treat a woman is to 'machacarla'49 (batter/crush her) and make her believe that she is always wrong about things. Guillermo and Mariano laugh again and I laugh along.

We walk off to get some food before Guillermo's daughter competes. We start to talk about hotel raids and it turns out that at 5pm the Valencia hotel got a phone call saying there was an inspection from the tax office. Guillermo had just arrived in Sevilla, so he had to drive four hours back to Valencia to answer their queries. 'Everything was in order, I am a professional' he concludes. 'There was no real problem, I did my homework before they came unlike some people,' he says as he spits bits of salad out of his mouth. 'I was there until 4am in the morning but they couldn't find anything to fine me with. They asked me to open the safe and it had $€ 5,000$ in I had accounted for,' he adds.

We finish the food and watch Guillermo's daughter come third in the championship; the women then leave for the break. I accompany Guillermo to congratulate his daughter. He confesses that he is 'fed up' with his wife who criticises him for what he spends his money on while he says nothing about what she spends it on. On top of this, he says she did not have sex with him for the last two months. I shrug my shoulders and show sympathy while putting my arm around him. He smiles, returns the arm hug and says 'mejor te zumbas lo que puedas y ya esta' (best just fuck as much as you can and that's it). We come back to the stables where we meet Maitre, Mariano's young girlfriend. She plays around with her phone and perks up when Guillermo says 'this is Mr English' and she looks down below her glasses. 'You are Mr English?' You are famous here' [Field notes].

${ }^{49}$ In this context, 'machacar' refers to psychological damage but can also mean physical damage. 
These field notes were taken only recently during my ongoing study on prostitution in Madrid. They reflect a relationship I have managed to covertly develop with Guilermo, the owner of three brothels, or as he calls them 'luxury hotels' ('hotel' hereafter). This earns him significant amounts of money: around $€ 50,000$ a week, which is why we are mixing with the upper echelons of Spanish society in a posh neighbourhood. The notes also reflect how Mr English, my alter ego, fits in with this social scenery of wealth and sexism. However, it is not all glitz and glamour nor is the role I play as 'Mr English' particularly easy or comfortable.

Since June 2016, I have been working covertly in one of Guillermo's hotels reviewing porn forums and teaching English. How did I come to do this? To cut a long story short, after moving to Spain in the summer of 2013 to take up a position in a university to develop their research profile, I was lumbered with significant teaching and administration duties that almost killed my research career. In the summer of 2015, I reduced my hours and signed a part time contract to be able to find other ways of earning money and undertake research. One of the ways in which I complemented my wage was to teach English.

I am not a qualified English teacher nor do I know how to teach English. However, in Spain, anyone English is seen as having an automatic ability to teach the language. I started by giving conversational classes to former students for the Cambridge English exams and was quite successful in helping them pass. One of those students spoke to a group of younger people in another town nearby wanting to learn English as well. After a few months, the father of one of the children - who is also involved in Guillermo's 'hotel business' - recommended me to him. Guillermo called me shortly after and said he had some work for me and I agreed to meet him. The irony is that the first day I met him I had already spent the morning in an uninspiring conference about prostitution where the country's finest and most experienced researchers were talking about a ground-breaking tool which would act as a means of effectively intervening in reducing harm to prostitutes engaged in problematic drug use (Cruz Blanca 2016). At the same conference, I asked them about their experience with prostitutes in brothels and it turned out that not one had ever set a foot inside a brothel.

I have been privileged to say the least. In the time I have been working in the hotel, I have managed to develop a strong relationship with Guillermo to the point where we have met for lunch, had dinner out in some of Madrid's finest restaurants, and gone to bars and got drunk together. He has also allowed me to drive his Jeep and Porsche. I have been invited to the Christmas party, met with his family and close friends and associates and seem to have become part of his inner circle having also had access to the 'bunker' he has in the hotel where he keeps numerous different firearms and riot gear, and significant amounts of money. I have also been invited to go shooting with him along with the police and civil guard staff he informally employs as additional security and am privy to how he avoids fiscal attention from the state tax system.

While the study is ongoing, I feel it is unique to any insight I can find about this type of indoor prostitution given its relative difficulty in researching (Sanders 2006; Weitzer 2007). Previous international studies seem to have some harm reduction agenda and/or relate to a particular feminist standpoint (Farley 2005; Cusick 2006): there is nothing 
wrong with this, however my study has accessed the ultra-masculine hierarchy of the hotel and its interactions and thus can offer a different perspective. Furthermore, most work is survey oriented; there is very little work which is qualitative and almost none which encompasses ethnographic approaches (Raphael and Shapiro 2004). This makes the approach unique, especially given the limited conceptions of sex work and the inability of criminological/sociological research in Spain to go beyond basic free-will choice explanations of deviance and crime (Briggs 2017; Briggs and Pérez Suárez 2016; Briggs and Monge, 2017).

At this stage in the study, this paper is a reflexive and methodological contribution discussing how I have come to manage my covert research (Winlow 2001; Treadwell and Garland 2011): Guillermo has no idea that I am a researcher, that I teach criminology or that I have even been documenting what is taking place in his hotel. This has meant that I have had to carefully manage aspects of my identity which contravene much of who I am and what I believe. Instead, I have adapted in many ways to who Guillermo is, how his circle of associates and collaborators operate, in line with security guards and domestic staff as well as the general cultural norms that govern the hotel space and the 40 or so women who work from it. At times, Guillermo has become cautious of me and at others I have almost been exposed for who I am. My main challenge in the future will be finding a way out of this. I begin by offering some context to prostitution in Spain.

\section{Foreplay: Neoliberalism, the Sex Industry and the Commodification of Intimacy}

While paying-for-sex is age-old, it was the international capitalist development in the 19th century which transformed prostitution into an international sex industry. The most recent period of globalisation and restructuring of capitalist production from the 1970s onwards has once again reshaped the sex industry as it has wreaked havoc with the lives of ordinary people. In developing countries, where this has been felt most, structural adjustment programmes imposed by the International Monetary Fund (IMF) increased displacement in rural areas, unemployment in urban areas and led to wage cuts and increases in poverty (Verloo 2007). For example, in new production zones of South East Asia transnational corporations ride roughshod over minimum wage and health and safety laws, leaving women working in precarious conditions which is why the booming sex industry has come to fill the gap left by wages paid below subsistence levels or the lack of any secure, paid employment (Coy 2016).

This has had a profound impact on gender inequality. Neoliberal policies have therefore produced a huge polarisation between super rich elites and the marginalised and desperately poor, many of whom are women who face little choice but to choose by surviving in informal economies such as the sex industry (Briggs and Monge 2017). This is certainly the case in Spain where the same processes which caused the economic crisis of 2008 exacerbated the marginal experience of thousands of women in the country. In a shrinking formal economy, it is unsurprising that many of these women sidestep into markets like the sex industry as a way of maintaining themselves and their families.

While neoliberalism has in practice meant that more women have entered the labour market, many have also entered its informal equivalent. There is less time to maintain relationships, especially in families, hence many use their grandparents in the 
childrearing process. This is exacerbated in a diminishing economy where both parents need to work longer and harder to maintain a family. The family structure is under constant threat. In this context, couples or families have lost meaningful time together; work is prioritised and people obsess about pending tasks and, in the process, lose perspective on their relationships. Spare time is consequently folded into pointless updates on Facebook, never-ending garble in Whatsapp conversations and almost a kind of emergency, fast-track parenting style where people try and cram in time with their children hoping to make up for what they have lost (Young 2007).

Much of this is evident by simply observing everyday life in Spain but complemented further by quite invisible changes to the cultural way of life since the late 1970s. Neoliberalism has also interfered with the cultural dynamics of family relationships and religious traditions associated with family life. Spain is a predominantly catholic country and up until the death of Franco in 1976 these religious values were very much embedded in the idea that marriage translates into individual sacrifices made for the collective or, in this case, the family. Yet while the rhetoric around marriage continues to reflect catholic expectations, those conceptions seem to implode in these postmodern neoliberal times which canonise individualism. So there then appears a tension: family collectivity is imprinted on a mode of cultural life which increasingly reflects the social and commercial pressures to attend and satisfy individualistic needs and desires (Žižek 2009).

This transition toward individualisation provokes disinterest in communal life, in what is best for society, and even to some degree family, and starts to reflect the neoliberal mantras like 'look out for number one.' This has warped previous notions of solidarity in the context of family. People become detached, disorientated from their family obligations, and lean towards the satisfaction of their own needs (Bauman 2011). There is a whole commercial industry producing these 'desires' and dressing them up as 'needs'. We are sold ideas about what we deserve and what we should be getting as a proof of our participation in the 'good life' (Briggs 2013). In this context, sex becomes an additional 'experience' sold as a commodity. In Spain, the sex industry is worth $€ 3,672$ million each year (Ruiz 2014): Spain is Europe's highest consumer of sexual services (APRAMP 2015) where around one in five men have paid for sex (Meneses Falcón 2015). It should be unsurprising then that prostitution is considered 'normalised' (Miguel Álvarez 2012). Indeed, it has been estimated that around 100,000 women practice prostitution in Spain and that it is the number two country in Europe with 'clubs or hotels' where sex is sold (Meneses Falcón 2015).

Neoliberalism also endorses a notion of free-will thinking - a common misconception attached to the choice of the prostitute is that it is a rational and calculated decision: the idea that women - conscious of what it means to prostitute themselves - openly consent to selling sex services. This is reflected in Spanish penal law which prescribes prostitution as alegal (neither legal or illegal). Articles 182 to 192 of the Penal Code updated November $25^{\text {th }} 1995$ stipulates that prostitution is not illegal when it is practiced by an adult and in a voluntary capacity. In addition, prostitution agencies often preach liberal ideologies about how women make free choices by their own will to prostitute themselves and therefore must make similar cognitive evaluations to leave it. Having 
spent 14 months with the women in my study, it seems clear that under no circumstances has the choice to prostitute been clear-cut or completely consensual and this is directly related to the necessity these women carry to support themselves as well as the demands of supporting a family. While their exploitation in the sex industry happens at varying degrees, the women in my study enter into these situations often having no job and/or having little other economic means to support a family (Briggs and Pérez Suárez 2016).

Though their autonomy clearly varies, essentially they are bound to prostitution as a form of socio-economic bondage: for many, it has become the only reasonable alternative given current austerity conditions in Spain. A shrinking formal economy has no room for women who are underqualified or lack formal education, especially during a time when temporary work is disappearing quickly (Requeña 2014). In this respect, objective circumstances determine subjective experience (Žižek 2016) and this blurs the idea that governs personal choice of entering into prostitution. Likewise, the question as to why they cannot work themselves out of their marginality becomes pertinent. In this paper, the notion of commercial bondage is put forward to explain how and why these women struggle to escape the precariousness of their economic and social circumstances. This concept shows how they are obliged and oblige themselves to compete against each other for clients and this involves an investment in extravagant consumer lifestyles, erotic capital (Hakim 2010) and body capital. All this directly relates to how the hotel space and the macho management structure operate as a means of generating capital.

\section{Mr English Enters the 'Luxury Hotel'}

As the time approaches 6pm, I walk up to the smart property which for a hotel has immensely high walls. I push on the door and walk up the immaculate stairs and buzz to get in: this is not the 'hotel' I had suspected it was. I walk past a well-built Russian security guard called Vlad who looks as if he could knock me out in a second. I am shown through into the waiting room which is a kind of plush living room with its own bar; relaxing music plays in the background. A short attractive woman offers me any drink I desire before I ask for a beer. She closes the door and I wait for Guillermo.

The short attractive woman then returns after 10 minutes and leads me back to the reception where a few women in high heels fiddle around in two of their lockers behind the desk. They are heavily made up as they hand over a fistful of cash to Guillermo who hands it to the receptionist. They then disappear as we sit in the back-offce area nestled behind the reception and start to talk while the intimidating Vlad folds his arms and stands next to me and looks down at me. There are a series of CCTV cameras angled at all the passageways of the hotel and a range of security alarms which control the front gates and doors of the property.

Guillermo then sits in front of me. He is unshaven and with unkept hair, he speaks abruptly and to the point. He asks me what I have been told about what he does and I confess to knowing little - though when three young women in fine dresses and high heels appear in the reception area I get the picture. 'Tou mean you don't know?' he asks as he laughs. 'VVamos es un puti club!,' (come on, it's a brothel!) he says and turns away from me to turn on the computer. More young women come and go and fiddle in their lockers. 'Es que habia aprendido en el colegio hace años pero no me enseñaba bien de hablar' (they taught me English a long time ago but they 


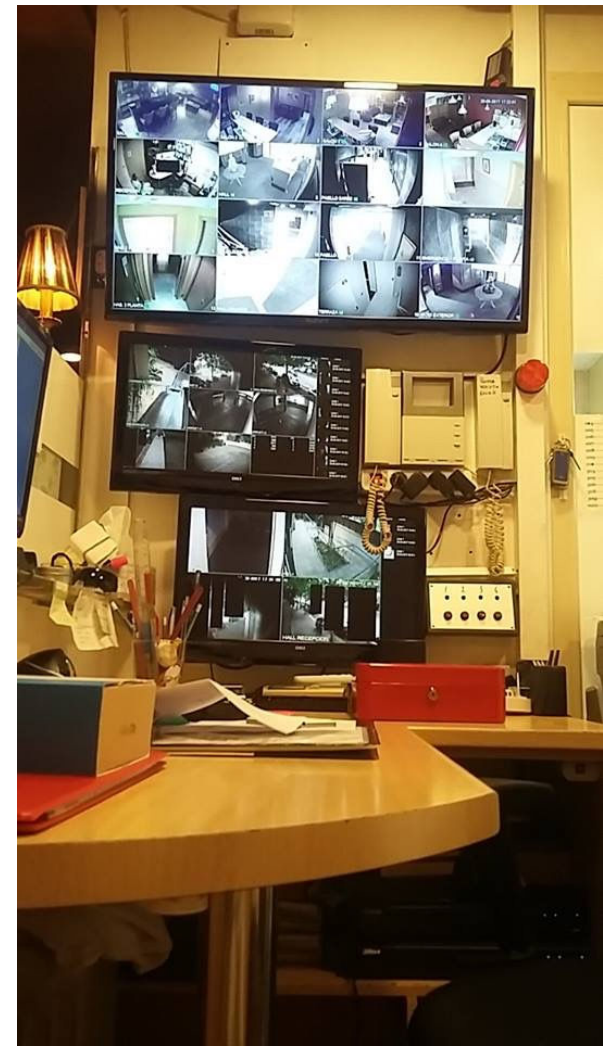

Fig. 1. Guillermo's CCTV system in his security office. Image: author, 2017. didn't show me how to speak well) he says as he looks down and swivels on his broken chair.

As we talk about his business, we are interrupted by a dispute on the third floor which requires Guillermo's intervention. He leaves me and reappears on his own CCTV cameras interjecting with three women who look to be visibly upset. 'Siempre pasa con las chicas' (it always happens to the girls) says Vlad in a booming voice and shakes his head. Vlad, who has been in Spain now for over a decade, says this is the worst job he has had as he says he has worked in the roughest nightclubs of Madrid. I try to work out what exactly is going on but before I can ask him more Guillermo leaves from Camera 3 and within 20 seconds returns to where we are.

Guillermo silently turns to his computer and brings up his website which is a glossy wannabe high-class prostitution service. As another woman in a towel hands him over $€ 140$, he then shows me his website which brims with naked photos of the girls working for him. He is envious of the international sex chat forums which mention his service - only he doesn't know what they say as they are in English. We fick through a few comments which recommend other rival services and he clicks on their websites, cursing at them saying they are 'una mierda' (shit) because they look 'cutre' (cheap).

After another tall blond comes over and hands another couple of hundred euros in cash to him, he explains how he wants me to give him English classes (so he can understand the international sex forums) and help him navigate what people say about the service he offers. 'Pero tienes que conocer el sitio, vamos' (but you have to be familiar with the place, let's go) he says as he leads me past the reception where all the women assemble in the main hall.

As they flick their hair around and brush down their short dresses which cling tightly to their slim figures, we walk first to the far right, passing several rooms well kitted out with a sofa and bar; 'aqui se caliente la cosa' (here things warm up) says Guillermo. In one room, an old bald man sits sipping a Heineken, looking anxiously around as we pass. Guillermo then shows me the standard rooms which could be any hotel room in Spain: a double bed, bathroom and thick 
curtains to deter the light from the night time activities. We go upstairs, the size of the room increases as does the price; the bathrooms are bigger and there is a huge mirror on the ceiling. Normally, 'una chica' (a girl) for 30 minutes costs $€ 70$ and for an hour $€ 140$ in the standard rooms but with the larger rooms, fitted with Facuzzi there is an extra $€ 55$ for the room per hour. As we walk, I ask Guillermo how much it is for two women. 'Lo doblas tio' (double it mate) he says. Normally the first alcoholic drink is free and then the client pays what they require.

We then return to the main reception area to collect the 'suite key' where we see more women assemble to present themselves to a new client who will choose one of them. We then take the lift to the third floor and exit out where there are only two main doors. It is warm when we enter as Guillermo unlocks one door and turns on the light to reveal an apartment which could easily be the set for Sex and the City except that this really is sex in the city. These apartments are $€ 300$ per hour of course plus the sexual services of the 'chica'. [Field notes]

My primary function thereafter has been twofold a) to review porn forums which have comments written in English from clients who come to the brothel (two hours a week) and b) to teach the manager English (two hours a week). Given that Guillermo's main concern when I first started was to improve the efficiency of his business, he dedicated the first two hours of my time to review the porn forums and collect information about what clients said as well as create false online accounts and leave positive messages about the hotel and its services. This required me to not only be creative with email names and passwords but also the types of characters I had to be online. This went on for a few months until many of the accounts were closed as most forums caught on to the fact that each of my online identities seemed to be posting consistently positive messages about the hotel. After six months Guillermo told me to abandon this and concentrate on teaching him English.

Given that I am not a qualified English teacher, I have had to learn how to become a teacher and learn how to teach English, though much of it is still improvised. I first used standardised modes of learning through books but it became clear Guillermo didn't have enough time given his busy schedule of travelling between his three hotels and family commitments. I then tried to engage more online modes of learning using whatsapp and sending him links but he didn't find the time to respond. In the end, I started writing notes up in a book and told Guillermo to try and find time to study it for his next classes.

As time passed in the hotel, I came to learn that I was part of a string of other entertainments for Guillermo. Outside the time he spent with me, he was fine dining, sleeping around with random women behind his wife's back, going shooting with his informal security staff which included a national police and civil guard officer and driving around on and off-road one of his eight expensive cars and jeeps. Most of these things seemed to give Guillermo very minimal pleasure and he showed regular disinterest in the typical conversations about these things with his circle of friends and contacts. Aside from sharing dirty jokes and videos of naked women, Guillermo and I came to enjoy talking about history, something which others showed little interest in. Indeed, many of the English classes simply turned into discussions about history. Between all this, I have managed to get quite an intimate view into the workings of the hotel. 


\section{The 'Luxury Hotel'}

The hotel in which I have been working is located around $7 \mathrm{~km}$ from the centre of Madrid in a neighbourhood which is neither extremely wealthy nor exceptionally poor. Most of the surrounding area is a mix of residential blocks of flats, houses, small businesses and within five minutes in the car, one can be on the M40 which is one of the main motorways that circles Madrid. From the outside, one would perhaps not catch on that it was a hotel and was just a hotel given the official plaque on the outside. However, once you push the high doors, inside there is patio and small Greek statue fountain. Up the steps, the thick glass door must be opened from the security office behind the reception once the client has been approved by the staff. Inside, the lighting is dim by the small lamps which sandwich famous works of Spanish art. In the middle of the wide space is a large round table with fresh flowers on and numerous cards advertising the hotel and its services.

To the immediate left is the reception area and behind it the security office and a fire exit where cleaning staff, deliveries are taken and where Don Condón (Mr Condom as they call him) comes to sell to the women condoms as well as other related sex products for their business. As one looks from the immediate left to centre, there is a toilet next to the reception and a cash machine before the stairs which drift up to the three floors of different styled rooms. To the immediate right is Bar 1, and looking back towards centre there is a stock room and a narrow corridor which trails past Bar 2, 3, and 4 before it leads to another fire exit where around 20 women share four bedrooms. The women don't live there per se but stay there for extended periods of up to three weeks, depending on the agreement they have with Guillermo. At the back there is a car park for hotel staff and for the women where most smoke in the time between their clients, surrounded by more high fences.

\section{How Prostitution Works in the Hotel}

There are around 40 women who work in the hotel; some more long term than others, who come for short periods of time, often either to fund further studies, pay off debt or/ and to establish some housing/family stability. For this reason, the population continually shifts and this affects the dynamics and relationships between the women. Every day new women send naked photos to the hotel mobile, a form of 'job interview' as the images determine their potential selection. For those who want to stay in the hotel and work continuous nights there is often a waiting list and some even have to prove themselves to be good earners before they can be considered to obtain a bed in the hotel. This normally happens when one of the women has a week off and/or they go on holiday. Nevertheless, the women cannot be away for too long it seems and this is related to their debt, how much they spend when they are away and how much they put aside for financial commitments related to family. They may also lose their 'spot' as there is intense competition between them with regard to their appearance and earnings.

While the hotel promises to be a potentially good earner for the women as most earn around $€ 5,000$ a month in cash (a few even earn up to $€ 15,000$ a month), it is also a work that is emotionally, mentally and physically demanding. The conditions are detrimental to their health and safety; most develop alcohol and drug dependencies to endure the long and arduous shifts as well as adhere to the sexual requests/fantasies of 


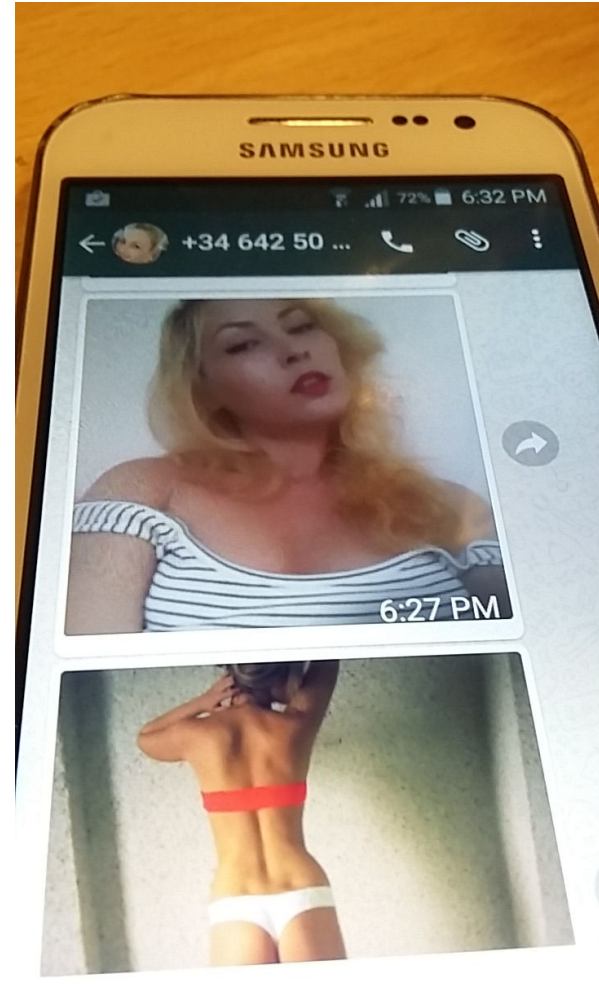

Fig. 2. Women send semi-naked images to Guillermo to see if they can get work. Image: author, 2017. the clients. In addition, many clients demand that the women take certain drugs and as bonus they are paid more.

The client will enter the establishment, be shown into one of the bars on the right, will be offered a drink from the bar and then shortly after begins the 'presentation' which is a kind 'female parade' in which the women flaunt themselves to the client, answer his questions and reveal a price. The client has a notebook at hand to take notes as the women enter and leave one by one. Depending on the hour (such as Fridays and Saturdays, as well as days when European football is broadcast), as many as 20 women can present but during afternoons, very few are available. Once the client has made his choice, the chosen woman will re-enter and they will go upstairs together to a room. Shortly after, the respective woman will come down with the cash to pay for the room hire - as she charges what she likes on top of that for a variety of services which vary from standard sex to things like hard-core anal to foot licking or just hugging and talking.

Between this, the women may be randomly interrogated by Guillermo regarding the 'legal questions' - the women are trained in protecting the establishment from covert council inspections and/or police raids. It is illegal to sell sex from closed establishments but not if the women rent the rooms themselves - hence the emphasis on ensuring that the women work for themselves. However, this is jeopardised because most of the women who have drug and alcohol problems don't always remember what they should say if interrogated about the hotel's operations and some women don't speak Spanish well. This coupled with the high turnover of women means that the social dynamics are constantly shifting and thus rules and regulations are frequently flouted and ignored. The result is that there is no stable working culture/environment and the supervisors, who come as often as they go because they get fired for stealing from the safe, struggle with keeping a sense of order: 
We are constantly interrupted during the class by two new Italian women who used to work selling sex in a private location in Ibiza. The two women look like sisters and have applied large amounts of make-up over their damaged and warty skin. Both have operated lips, face and breasts; they stand practically bare-chested in front of Guillermo who only looks down as he goes through the legal questions. The tall blond whose lipstick seems to fall off as she speaks barely speaks Spanish and has to communicate through her sister whose level is marginally better. They get some of the questions wrong about the fact that they charge money and about the shift lengths: Guillermo grits his teeth and reminds them.

They leave to continue presenting themselves as Guillermo then summons a girl called Gabi and tells her off as well for not coming down earlier to present when her shift started at 6 pm (it is now 7 pm). Guillermo then explains that he needs more women as the business is picking up and too many start work but stop after a few shifts. He convenes two more to the desk before asking them if they have any friends who want to work. Another new girl, who seems to be from South America, comes to the desk in what looks like some sort of sexy wonder woman outfit. She gets her cracked mobile out and starts showing us one of her friends who is ' 40 years old but looks 30' as she describes. 'There are other two', she says, but they are 'illegal' and 'don't have the papers yet'. Guillermo nods and invites them to send him some sexy pictures. [Field notes]

This makes the work extremely precarious because none of the women have a contract per se as they work self-employed - not that this form of work is official nor can be registered with the social security offices since prostitution in Spain is not a profession. There is constant economic pressure on the women to earn money which creates significant competition between the women and causes many other problems. While many use drugs and alcohol to not only cope with the nature and frequency of their labour, they are also in the main obligated by the clients to enable their sexual fantasies. While many seem to try and maintain a brave face, it is clear that underneath there is significant suffering which many seem to buffer by investing in their bodily appearance and a range of expensive consumer goods which may reflect otherwise that they are 'prostitutes'. All this is furthermore amplified by Guillermo's laborious network of CGTV cameras which only perpetuates a sense of insecurity, paranoia and, in a few cases, suicidal feelings.

\section{Security}

Guillermo's use of CCTV cameras is one of many measures he takes to prevent the ever-present risk of an armed robbery since other similar establishments are robbed on a daily basis (there have been cases within two square miles of the hotel). This is also why Guillermo stores several shotguns, various pistols and machine gun in his secure bunker on the third floor of the establishment. Guillermo also informally employs a National Police and Civil Guard officer to assist in curbing potential problems. These people also assist when legal barriers present themselves such as fines, inspections, etc. Two Russian men - one of which holds a day shift (Vlad) and a night shift (Andrei), also patrol the reception area to deal with problematic clients and potential robbers. This is because dangerous clients also come in and Guillermo wants to be assured he is ready for this:

...we are abruptly interrupted by a sudden invitation from Guillermo to see his weapons. I agree and leave the seat and walk with both him and Pedro past a few girls in the hallway and into 


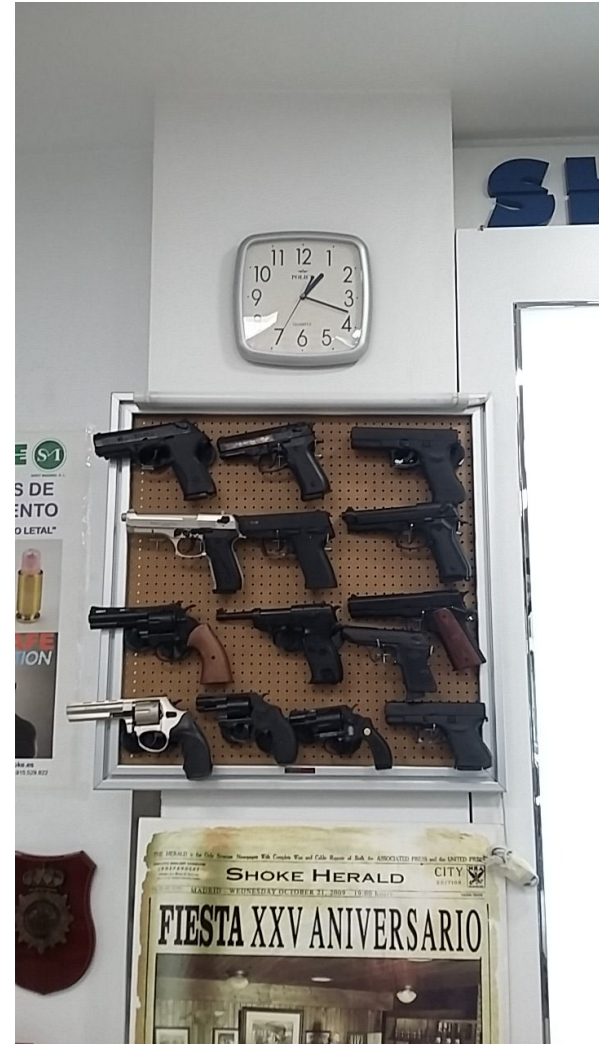

Fig. 3. Gun shopping with Guillermo after one year of fieldwork. Image: author, 2017. the lift. We go to the third floor where it is hot and humid and walk along the corridor to Guillermo's bunker. He pulls out of his shorts a keyring which unlocks the four bolts on the other side of the thick metal door before unlocking it with another key. Inside, the small studio flat it is a bit messy with clothes and magazines, and on the bed is a small fortune and a laptop. Guillermo goes over to a small metal cabinet and unlocks it. Out he pulls a shotgun and proudly holds it lately I am hitting $100 \%$ of the plates when I go out shooting,' he says as he aims the gun at the wall. He then shows us the large cartridges which go with it, explaining how each bullet has nine small balls in (I suppose shrapnel) which split when fired. Down at the bottom of the bed is a riot helmet which Guillermo says is completely bullet proof as well as a thick vest which can take shots from the shotgun. I smile politely as he shows me all this and pull amazed faces, asking to hold the gun; it is not even that heavy as I take it in my arms and feign firing it at the wall. I ask him whether there is a real risk and he shows me a news article on his telephone of a robbery in which the offenders stole $€ 40,000$ in cash as well as jewellery and other things stashed in the safe. [Field notes]

Throughout the fieldwork, though varied in their socio-economic profile, Vlad told me that some of the clients were wanted by the police and a few even for murder. Guillermo was also concerned about what the women knew about him since, over the last few years, some of them had tipped off hitmen to raid and rob the establishment. Guillermo's preoccupation with security over the course of the fieldwork period slowly increased and after five months of the study he managed to obtain a licence to carry a gun with him. To this day, he attends a shooting range twice a week to improve his accuracy, and frequently boasts about his abilities at 'hitting people in the chest' as well as 'improving the aim with the left hand' because 'you never know if your right hand will get hurt or damaged so you need capacity with both'. While Guillermo seems to be a placid character, there have been very anxious moments where his passive state has been abruptly disturbed when he got angry. He seems to be a nervous person who tries to give of a sense of personal stability. Jokingly one evening, when we were out to dinner, he said to me 'I have no problem to kill someone in my hotel, this I can justify 
but if we are out in public, it becomes a bit more complicated,' and laughed. I don't doubt he can do this after hearing his tales of fighting in Afghanistan and killing people as well as the times he has showed me, without emotion, videoclips of people being killed.

\section{The Clients}

The clients vary in age and nationality, ranging from young men in their late 20 s to those in their 70s. Some are local and regular clients while others are tourists and some are retired and powerful politicians, businessmen and other professionals. Almost all seem to be in relationships/married and have the capital to spend between $€ 100$ and $€ 1000$ on sessions with prostitutes for services. Most of these people tend to have expendable money and often pay more to take drugs with the women or for them to take drugs while they engage in sexual activities with them. This can range from just talking, getting a hug and drinking to a range of sordid sexual acts which can involve objects, pissing and shitting and bondage-like rituals. Very often there is the expectation that if powerful politicians or 'gente de la casa' (powerful politicians or wealthy regular clients) then the requests for the women are taken more seriously and one or a number of the women can be summoned to serve should one of these men come through the door. The hotel is also a haven for professional criminals as I came to know after having been told about a group of four English men who came into celebrate their 'pay days'. Vlad told me 'here we don't ask questions if people are spending, it is their business, take these four English guys who come in the other day they spent $€ 6,000$ in 20 hours so of course they are welcome here'. I was later to briefly meet them:

When I walk up the steps, Leena, the supervisor says 'here are other English men' and she introduces me to them. They stand there drunk, frowning at me wondering if I am English or not before one says 'you're not English mate' in an East-end accent and when I tell them I'm from Camberwell, the blond one pulls a face while a bald one goes to the toilet. They are the regulars here and spend a lot of money; in the words of Vlad 'they are good clients'. 'The whores are cheaper here mate' shouts the blond English guy as they start to wonder off together into Bar 1.

I walk past them into the security office while Leena directs them to the bar. Soon after, she turns off the camera to 'let them eat and drink without being watched'. She rushes around trying to locate one girl (Colombian) who they demand to see first. It seems as if she has another client and in a panic, Leena screams down the tanoy 'presentacion en el bar 3'. I sit down with Vlad and he looks tired. He has been away since 3 am doing a night and day shift as the regular night shift worker has missed a plane and couldn't work his shift. The girl who the English men want to see suddenly appears doing her make-up and changing her shoes in the reception area. She rushes in to present herself: apparently, she is popular with them and Leena adds 'one of them will have her for a few hours and she always comes down exasperated'. Thereafter the English men - all with their sunglasses on - each retire up the stairs with a girl each on their arm. 'See you later Camberwell' says one jeeringly. [Field notes]

The forgotten stories of the hotel are clearly those of the women who are seen as fuck objects; a transaction made for a service to be obtained. 


\section{Socio-economic Bondage: The Decision to Prostitute}

The decision these women took to prostitute is not clear-cut and is related to the almost impossible scenarios they have felt as a consequence of a shrinking labour market, which is by the day affected by national and local Spanish companies contracting out cheaper labour in foreign countries. This form of socio-economic bondage binds them to particular grey areas in the economy such as that which makes up Spain's growing sex industry. Coupled with family responsibilities, the decision to prostitute becomes one of having no choice but to choose and this was the case for 'Paula':

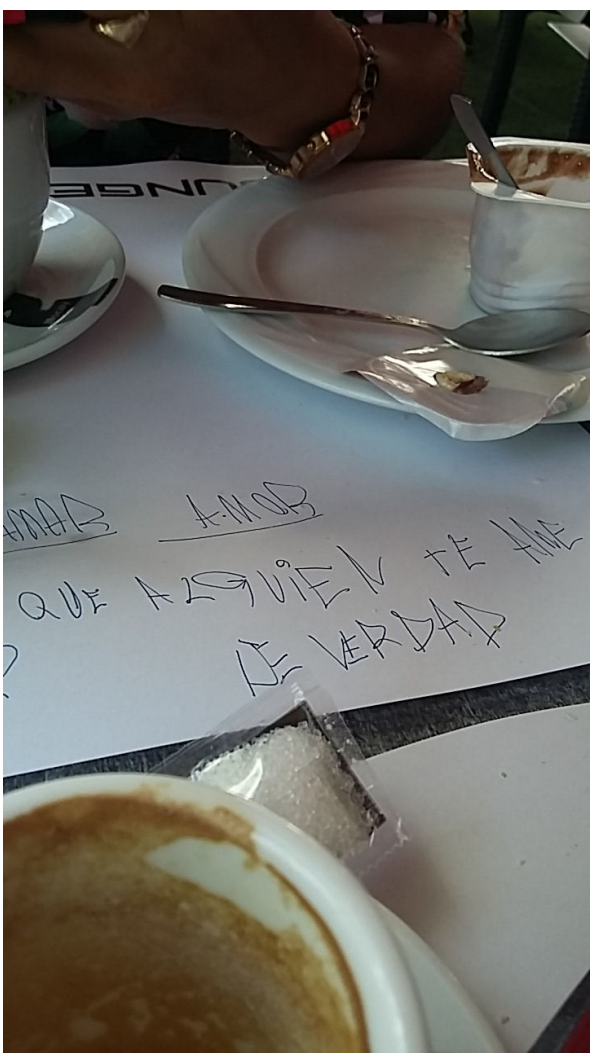

Fig. 4. Talking to Gema - the notes say: 'someone who truly loves me', in response to the question of what she really wants. Image: author, 2017.
As she sits down, I notice the wrinkles on her face come through the makeup. At first she doesn't look me in the eye but when I ask what her name is and she says Paula, I sound unconvinced and ask her 'what's your real name?' 'Gema' she says and beams a smile 'but we don't normally call each other by our real names'. She sits calmly, cross legged. Initially from Valladolid, she moved to Madrid to find work in 2005 but was laid off shortly after. As it transpires, she has spent one year in the hotel previously working in all sorts of jobs; the most recent, a plastic factory in Fuenlabrada [a poor postindustrial part of Madrid where unemployment is high which was hit badly by the financial crisis of 2008. Thereafter, it made redundancies year after year and contracted Chinese personnel to work. Her situation was made more complicated with she divorced and her son developed some health complications. She says she copes with the work, she can choose the clients and no one is obligating her and it is good money. 'Its not all sex, some people come in her and their lives are in shambles, they want a hug or just to talk so it's a mix' she says. [Field notes]

While on one hand, the perks of the job include the choice to choose the client, the emotional and physical demands of her work are heavy; she has frequently complained to me about having major back pains from

working a whole weekend without sleep and rarely smiles on a day-to-day basis. Paula is concerned that her son will find out what she does which would be 'a nightmare come 
true'. However, to cope with the work, Paula takes cocaine every night and drinks heavily. Like Paula, many women reflect on these kind of conditions which made them contemplate prostitution and this can be traced directly to the current precariousness of the labour market and rampant competition for temporary work. The hotel, therefore, becomes for many somewhere where money can be made quick. This was the case for Paloma who I met in September 2016:

I ask Maria, the supervisor, about the new women in the club and how so many now seem to be around early in the day but our conversation is interrupted by the arrival of two new young women from southern Madrid. Both aged 20, they are sisters although look totally unlike each other, 'only by mother' says Sheryl in a tight blue skirt as her curls dangle over it. The other, thinner and more pail, who has scars and cut marks down her wrists, has a kind of cross-eyed look and I'm not sure if she is looking at me as she talks and adjusts her purple gusset type top which are filled with her large breasts. Her name is Paloma. They have only been at work a few days it seems and feel the pressure and competition, and as they complain/worry about their potential to get clients, they lean over and sigh on the reception desk. [Field notes]

One week later, however:

The presentations continue and Vlad tells me how Paloma was sacked by Guillermo - though Vlad communicated the news as Guillermo didn't want to. Paloma, it seems, was wanted by the police for several offences including violence against a police officer. To me she looked as if she had had a hard life for when I saw her arms they were scarred and bitten. Somehow Guillermo had got hold of pictures of her legs and upper arms which had large circular-like scars on; it looked as if she had been tortured or something. Posing as the sister in law of Sheryl, she had tried to work in the hotel but Vlad said she had no interest from the clients: no man wanted to have sex with her. 'She will disappear, but we can't have risks like that in here' says Guillermo. [Field notes]

I was fortunate in this short time to talk to Paloma who came from a working class background, had drug problems and was in and out of school. She had a criminal history and spent some years on the run from the police. Her experience is typical to this part of the sex industry. If the women don't take clients, they earn no money: they have no choice. Moreover, although from the outset, these working conditions may seem reasonable given the pay, other precarious circumstances arise in several formats related to the danger to which they expose themselves in the rooms with the clients (as legally they are not protected from what happens as they have rented the room and what takes place in there is consensual between two parties).

\section{From Socio-economic to Commercial Bondage: Self-objectification and Decisions to Stay in Prostitution}

The significant competition for clients and social status between the women causes many arguments in the hotel. Naturally, this competition is evident in their disputes which many times Guillermo has to end up resolving as the female supervisors' struggle with intervening and the male security staff show no interest. Physical appearance, therefore, becomes intrinsic as a means of navigating these quarrels. As noted earlier, while many women earn large sums of money, much of it is spent on consumer goods 
and is reinvested in their bodies (hair, nails, botox injections, operated breasts); many simply become caricatures of themselves and this physical transformation only feeds the meritocratic pressure which the space and context impose on them to earn more money, compete with other women, take extravagant holidays and buy expensive commodities as proof of their participation in consumer society:

I continue my conversation with Leena and we get talking about the women's earnings and spendings concluding, as she puts it, that many are in significant debt if you earn a lot of money, and you aren't clever how you use it, it goes'. She then says that many of the women spend a lot of money on their bodies and other clothes and commodities to retain their youthfulness and attraction, 'casi todas están operadas' (almost all are operated) she says. [Field notes]

The object nature of their existence seems to be reinforced by the continual expectancy to provide sexual services - given the lack of alternatives but with clear consumer rewards and ideological social status - and augmented by the mostly male-oriented management structure, which taken together, produces a sort of a self-objectification of their gender. What seems to happen then is that various emotional and psychological traumas of past experiences and daily labour are subjectively anaesthetised by the recompense of seemingly never-ending participation in a hyper-sexualised, microconsumer world which is driven by the demands made on the women as much as those which they make on themselves and this is what seems to encompass their selfobjectification.

\section{Establishing Mr English}

It is into all this that has stepped Mr English, or if one would have it, the role I play:

Guillermo and I sip our beers and watch the women parade in and out as they make presentations and fiddle on their phones as they wait. Two new girls from Ecuador come in and Almudena takes their identificatgion as they wait nervously looking over at us. 'Very short looking' says Almudena as Gabi then comes down to show them around. A very young skinny girl then comes up to us with large breasts; her operated lips make her face look disproportionate and she holds her stomach as if she is feeling ill; one arm is almost entirely decorated with tattoos. She wanted to go to the pharmacy to get some medication but she was told to wait for a client who had asked specifically for her. She returns to the reception area as Don Condom comes to the door to sell sexual-related goods. As I leave, Guillermo jokes how I should dress up in a Santa outfit for the whole month of December as Santa Claus singing Merry Christmas. I joke and pretend to shake hands with a client as he leaves in the reception area tho ho ho espero que hayas echado un buen polvo' (ho ho ho, I hope you had good sex with us) and he and Jaime laugh as Guillermo says 'Mr English y su bromas' (Mr English and his jokes). The role is becoming me. [Field notes]

In these notes, taken some six months into the research, I reflect on how I have become the role of 'Mr English' as well as how it was becoming me. This had not always been the case since for some time I had dedicated myself to cultivating some form of identity which could allow me to act comfortably in the hotel. In particular, the security staff were extremely cautious about my introduction to the hotel and this made it difficult to 
offer too much curiosity to how things worked as it would have generated increased suspiscion. This meant that any research agenda needed to be stealthy managed to learn and know how this respective cultural field operated. Aspects of my research identity have had to shift in accordance with the social and cultural variables of the hotel and, later on, in other contexts with Guillermo. For example, when I first met Guillermo, he called me by my first name, then after some time it changed to 'Profe de inglés'. However, over the months it has become 'Mr English' and since remained thus. This transition has produced a shift in my research identity which the following figure indicates:

\begin{tabular}{|l|c|c|c|}
\hline \multicolumn{1}{|c|}{ Aspect } & \multicolumn{3}{|c|}{ Identity shift } \\
\cline { 2 - 4 } & Daniel & Profe de Inglés & Mr English \\
\hline & From 3 months & From 3-6 months & 6 months onward \\
\hline $\begin{array}{l}\text { Personal } \\
\text { characteristcs and } \\
\text { demeanour }\end{array}$ & $\begin{array}{c}\text { Formal, polite, } \\
\text { curious, aloof }\end{array}$ & $\begin{array}{c}\text { Informal, polite, } \\
\text { jokey, confident }\end{array}$ & $\begin{array}{c}\text { Brash, direct, jokey, } \\
\text { arrogant }\end{array}$ \\
\hline $\begin{array}{l}\text { Working relations } \\
\text { with Guillermo }\end{array}$ & Punctual, formal & Flexible, formal & Informal \\
\hline $\begin{array}{l}\text { General interaction } \\
\text { with prostitutes }\end{array}$ & Low & Medium & Low \\
\hline Access to associados & Minimal & Commonplace & Commonplace \\
\hline $\begin{array}{l}\text { Access to } \\
\text { interesados }\end{array}$ & Occasional & Minimal & Commonplace \\
\hline $\begin{array}{l}\text { Access to inner } \\
\text { circle }\end{array}$ & Never & Very occasional & Commonplace \\
\hline $\begin{array}{l}\text { Observations of } \\
\text { weapons }\end{array}$ & Minimal & Common & Almost everyday \\
\hline $\begin{array}{l}\text { Confessions of } \\
\text { corruption }\end{array}$ & Never & Occasional & Commonplace \\
\hline Invitations to travel & Never & Occasional & Commonplace \\
\hline $\begin{array}{l}\text { Invitations to } \\
\text { eat/dine/drink/go } \\
\text { out }\end{array}$ & Rarely & Medium & Almost weekly \\
\hline $\begin{array}{l}\text { Invitation to family } \\
\text { events }\end{array}$ & Never & Rarely & Often \\
\hline Trust level & Low & Medium & High \\
\hline
\end{tabular}

'Daniel' was initially someone curious, ignorant of things and perhaps taken back by proceedings in the hotel, partly because he was alien to them both socially and culturally. Daniel was formal and polite, even reserved avoiding confrontation and made jokes to neutralise tense situations such as these:

Vlad stands in the corridor smoking a cigarette which he holds outside as if it makes no difference that the smoke is drifting inside. There is some tension in the air as I come in and it seems I have walked in in the middle of an argument between Vlad and one of the women. I sit 
down and make a comment about the shitty state of the chairs to which Vlad replies how they are 'not for sitting on'. I then get up and pull a disgusted face and he starts to laugh. 'Me caigo bien con Daniel' (I get one well with Daniel) he says and punches me hard in the arm. [Field notes]

Winning the trust of Vlad and Andrei - the main security staff - was key to allowing myself to get to know Guillermo. In the early months of the study, they used to crowd the security office where I worked on the computer or where I talked with Guillermo, almost monitoring me. However, this was relaxed after some months and in time I came to know the 'asociados' (people who work and collaborate with Guillermo on a basic, professional and legal level), 'interesados' (people who also work for Guillermo but essentially take advantage of Guillermo's economic power and social status for their own benefit) and members of Guillermo's 'inner circle' (Guillermo's most powerful allies which include connections in political factions Pápa, Raul and Jaime - in short they are his friends with whom he spends most of his social time). Once 'Daniel' saw that it was beneficial to go along with and laugh at racist, misogynistic and sexist jokes/comments, agree to some respect on how women are seen in the hotels and show fascination and wonder for tales of violence and war (since Guillermo served in the military), then he became increasingly admired. In some ways, I had little choice for if I was to fail to respond to macho banter, I was branded 'gay' and this is not a label which carries weight in an ultra-masculine environment where the norm is the sexual conquest of women. So Daniel as a character could not have lasted long and had to concede somewhat to an ultra-masculine identity.

After three months, Guillermo started inviting me to lunch and dinners at which he would introduce me thus 'this is my profe de inglés' meaning 'English teacher'. These social events connected me to members - at all levels - of Guillermo's operations while at the same time gave him a sense of kudos; that he was learning a language which would help elevate him in the world of the rich and famous in which he interacts such as those described in the field notes at the beginning of the paper. On many occasions during these times, I was almost constantly dragged into sharing my opinion about the women in the hotel, women in general, and/or fucking and putting up with borderline practical jokes:

During our fine dinner of squid and various other Galician dishes, it transpires that Guillermo fired his night-time supervisor for charging clients for drinks even though he invites for the first drink for the rent of the room. As the women serve our food, faime and Guillermo dribble over them and joke about how they are 'in the market' (their term for looking for women to sleep with). We get on to the subject of the women in the hotel and Guillermo shows me Sweet naked on his phone and asks me who I like from the hotel. I confess to wanting to 'fuck Laura' because she is 'natural looking' and am then congratulated for my choice: the fact that I finally disclose something about how I supposedly feel about the women is met with relief and they continue the banter about the them. Faime apparently loves 'big tits' as Guillermo says 'Merche has the best tits, but good choice Mr English'. [Field notes]

And: 
Raul and Guillermo then appear from nowhere and start to cajole with me in the security office. I start to sweat slightly when they say 'we need to talk to you about a problem'. At this point I think my cover is blown and they have either found out I am a researcher or that I have been writing down what happens in the hotel. Neither of these is the case as they ask me to 'guarder unas pistolas y armas' (look after some guns and weapons) and Guillermo hands me his gun. As I hold it and start to nod as if I accept the challenge, there is a pause before the joke comes out and they snigger to themselves while Maria tries to avoid pulling a neutral face over her smile. [Field notes]

The transition into 'Mr English' has come at a cost for I have had to spend many nights out, often arriving home late some mornings and has gone from toleration of Guillermo's racist and sexist comments and blaze nature about women and fucking to reproducing them. Mr English is more brash and direct, he shares personal aspects of his life and history, and is not afraid to share tales of his sexual deviance, laughs hard and long at stories which relate to others in the inner circle which he has come to know. He helps himself to drinks when he wants and can go about the hotel at his leisure. He is privy to Guillermo's weapon store, the details of his affairs and sexual frivolity, admires the photos of the women he sleeps with and congratulates him on them. $\mathrm{Mr}$ English knows even his bizarre fetishes and sexual desires, as well as his feelings about his wife and family and knows his favourite food and where he likes to dine. He is asked his opinion on Guillermo's business direction and how to manage conflictive dynamics in the hotel. Mr English is at the centre of jokes and is granted licence to make them to others. He is embraced instead of hand shaken. He is back slapped instead of cautiously evaluated. He is invited rather than excluded.

Curiously, the shift from Profe de Inglés to Mr English produced a tension in the relationship I had with some of the women in that it meant I had to leave many relations behind and recommit to the audacious sexist and macho attitudes of those around Guillermo; after all, one cannot remain in an inner circle and be seen to start caring too much or showing too much concern for the women in the hotel. While there have been exceptions in that Mr English remains in close contact with several the women, this is often done outside the premises in order to not mix the two identities: one identity which flanks with Guillermo and another which is the complete opposite to everything he embodies and which is akin to Daniel.

The culmination of Mr English has also resulted in being given various assignments which I have somehow managed to avoid without losing the benefits of being $\mathrm{Mr}$ English which are only related to his access to information and little else. Mr English has been asked to 'test' out the other hotels as a mystery shopper (all paid for of course, including food, drink, woman and hotel). He has been asked to go to another local private sauna with Jaime, the National Police officer involved in his operations. He has also been asked to go to Germany to collect a new car which Guillermo had purchased for $€ 150,000$. Mr English is therefore much more than a Profe de Inglés and resembles nothing in relation to Daniel: he is emblematic of what is around him and to maintain his presence he obliges in the reproduction of the very cultural milieu in which he is working. 


\section{The Climax: Hardcore Ethnography}

This began as temporary work recommended to me through a friend. I didn't expect to turn up in a luxury hotel working for Guillermo and or that after one year I may be in a position to be starting to offer new insights into how this kind of indoor prostitution functions. What I am saying is that I never expected this even to become a potential research study but having been placed in this situation and being given this potential access, it became difficult for me to ignore what was going on given my research profile and methods which I used to study social groups. Since then, I have carefully documented what I could about how I have become immersed in this world and what new insights it can offer us into how prostitution works as well as the incestuous links with powerful political and social structures.

To some degree this is suspicious, since if the dominant ideology of decision-making with regard to prostitution in Spain relates to that taken by empowered women, it means that all other socio-cultural and structural pressures are removed from consideration. This is reflected in Spanish policy and law and partly explains why prostitution as a profession or activity is perhaps considered something autonomous and punishment is potentially directed at clients or buyers. Nothing changes, the sex industry in Spain is almost intrinsic to cultural life: it is entirely functional which means there can be no clear policy on its eradication nor can there be great commitment to its safe management. For this reason, legal loopholes emerge and new spaces for its operations emerge and this is what seems to have happened in the case of Guillermo and his hotels. As the economy continues to contract, new women will continue to begin to work for Guillermo and the business ticks over producing this socio-economic bondage: women who have limited options in formal labour markets and are bound to surviving in grey sectors of the economy like the expanding sex industry.

And Guillermo? He would argue, as he has done many times to me, that he is simply exploiting a market opportunity. His place in time, space and history is one of a neoliberal entrepreneur; a business guru who 'is his own boss'. He could be seen as the ultimate female oppressor, someone uncaring to his workforce and totally benefitting from their misery. After all, he is responsible for the working conditions in the hotel; he enforces the stringent rules, puts pressure on the women to compete with each other and can be ruthless when it comes to ensuring they comply with the frequently-changing dynamics. Nevertheless, the women he invites to work from his establishment need money, need some economic stability and for this reason there is a seemingly neverending stream of them coming into the hotel for work - replacing the previous ones who could not cope with the competitiveness of the work, its arduous nature and/or the oppressive environment.

Since starting the study, I have seen women come and go and others adapt and change; seen them increase their competitive edge by investing in their bodies, spending time in the gym, money on expensive consumer goods and on operations to improve their appeal. I think this reflects a kind of commercial bondage: once immersed in the space and dynamics of the hotel, the chances of problematic drug and alcohol use increases and decisions to continue in prostitution revolve around the financial investment and repair of the body in order to remain competitive. Its clear the micro-spatial dynamics endorse 
these antagonisms and much of this is reflected in discourses of looking good, how much certain designer clothes are and who does which type of sexual service better than the other.

Though I do not know exactly when and how it will end, I will at some point have to withdraw and this will mean completely severing my ties with Guillermo and his world. While the thought of this is welcoming, at the same time, it is disappointing since after all Guillermo is a human, he has a family, he has feelings and to some degree I have started to understand his world and why he may see it that way. I have become his friend in some way. Radical feminists will frown on me for stating this but my unanticipated intention in this study has always been to expose gender inequality related to this particular arena of social life. I have had to do this by participating in precisely the interactions which support and sustain it. For me, this has been stressful but I am fortunate to have an ability to do this kind of research and I hope you will agree that the benefits of having access to this hyper-masculine world outweigh the presence of $\mathrm{Mr}$ English.

This is because on a broader level there is a more disturbing story to be told which relates to the trajectory of the essence of human feeling. Consider the range of services the women offer and the clue to why this is happening seems blatantly obvious. Their 'need' here goes beyond a fuck or a blow job and although undoubtedly they relate to sexual gratification, this seems to be more about the absence of intimacy. These men lack intimacy, they lack time with their loved ones which is not to say they are victims of neglect. They also produce their own distance: long hours at work, distractions on mobile phones, and so on, for it is a distance which is structurally and commercially determined; they are subservient to a political economy which requires them to work longer hours for a job which they could lose at any point. They are purchasing an experience which is supposedly aimed at filling that emotional void, but it does not. There is nothing to fill that gap and this represents the commercialisation of our culture: experiences for sale, stories to be got. In the end, it means nothing. The transactional element of paying for sex ultimately eliminates its emotional significance.

Witness the lack which exists in Guillermo's life; he is constantly paying for things, spending large sums of money on the false promise that it will make him happy. The lack of time with his wife combined with the ultra-masculine management structure inevitably influences how he thinks about women. As I write these words, he maintains ongoing affairs with two women, has his own private telephone to accommodate their communications and regularly visits other brothels and saunas and pays for sex. All to be able to tell stories but deep inside he is very unhappy: lost in a perpetual cycle of spending and consumption which supposedly gives him a higher social status. Yet all it feeds is a constant need to earn more money and the pressure in managing the complications related to his 'business'.

Then there are the experiences of the women; in this context, emotionally hollowed out by a form and frequency of this work which drains them of their most precious intimate feelings: Tatiana refuses to have boyfriends who want to have sex with her but who only 'buy her things'. The trauma of the work for many rationalised as recompense for simply reflecting the need they have to feel economically included and an ability to have 
an occasional consumer splurge, a handbag or a pair of new shoes. Everything is for sale, everything has its price, but no-one has any conception of value, of virtue, of what it takes to live a life in which we can be truly satisfied and content of who we are and what we have become. And at the fundamental level, it is this commercial assault on our most precious human feeling - intimacy - has only catastrophic results. We lose interest, we drift, we neglect, we ignore and traces of genuine feelings fade away like a forgotten memory. The commodification of intimacy erodes us as all we end up doing is looking elsewhere for something which we won't find or can't replace.

APRAMP. 2015. La trata con fines de explotación sexual. Madrid: Ministerio de Sanidad, Política Social e Igualdad.

Bauman, Zygmunt. 2011. Culture in a liquid modern world. London: Polity Press.

Briggs, Daniel. 2013. Deviance and risk on holiday: An ethnography of British tourists in Ibiza, London: Palgrave Macmillan.

Briggs, Daniel and Monge Gamero, Ruben. 2017. Dead-end lives: Drugs and violence in the city shadows. Bristol: Policy Press.

Briggs, Daniel. 2017. "Los siete pecados del capitalismo académico y el crimen de la ciencia: Deconstruyendo la ideología de la "ciencia criminológica" en España".Criminología y fusticia Refurbished, 3: 1-27.

Briggs, Daniel and Pérez Suárez, Jorge Ramiro. 2016. "S3X_P0rn _HOTGIRLZ69: Un acercamiento a la prostitución desde la marginalidad y el ciborg". Criminología y Justicia Refurbished 6: 40-60.

Coy, Maddy. 2016. Prostitution, Harm and Gender Inequality: Theory, Research and Policy. London: Routledge.

Gruz, Blanca. 2016. Guía metodológica sobre prevención, reducción, detección, derivación y acompañamiento de situaciones de consumos problemáticos en contextos de prostitución. Madrid: Cruz Blanca.

Cusick, Linda. 2006. "Widening the harm reduction agenda: From drug use to sex work". International fournal of Drug Policy. 17: 3-11.

Farley, Melissa. 2005. "Prostitution harms women even if indoors". Violence against women. 11: 950-964.

Hakim, Catherine. 2010. Erotic capital: The power of attraction in the boardroom and the bedroom. London: Basic Books.

Meneses Falcón, María Del Carmen. 2015. Apoyando a las víctimas de trata Las necesidades de las mujeres víctimas de trata con fines de explotación sexual desde la perspectiva de las entidades especializadas y profesionales involucrados. Propuesta para la sensibilización contra la trata. Madrid: Ministerio del Gobierno.

Miguel Álvarez, Ana. 2012. "La prostitución de mujeres, una escuela de desigualdad humana". Revista Europea de Derechos Fundamentales 19: 49-74.

Requeña, Pilar Monreal. 2014. "Pobreza y exclusión social en Madrid: viejos temas y nuevas propuestas". AIBR: Revista de Antropología Iberoamericana 2: 163-182.

Ruiz, Javier. 2014. "Drogas y prostitución mueven en España 9.127 millones de euros, un 0,87\% del PIB español." Vozpopuli 25 September.

Sanders, Teela. 2006. "Sexing Up the Subject: Methodological Nuances in Researching the Female Sex Industry". Sexualities. 9: 449-468. 
Treadwell, James and Garland, Jon. 2011. "Masculinity, Marginalization and Violence: A Case Study of the English Defence League". British Fournal of Criminology. 51: 621-634.

Verloo, Mieke. 2007. Multiple meanings of gender equality: a critical frame analysis of gender policies in Europe. Budapest: Central European University Press.

Weitzer, Ronald. 2007. "Prostitution: Facts and fictions". Contexts. 6: 28-33.

Winlow, Simon. 2001. Badfellas: Crime, tradition and new masculinites. London: Bloomsbury.

Young, Jock. 2007. The vertigo of late modernity. London. Sage.

Žižek, Slavoj. 2009. The Plague of Fantasies. London: Verso.

Žižek, Slavoj. 2016. Disparities. London: Verso.

Daniel Briggs, PhD is a Consultant to the British Foreign Office who works part time at the Universidad Europea in Madrid, Spain. As a researcher, writer and interdisciplinary academic who studies social problems, he has undertaken ethnographic research into social issues from street drug users to terminally ill-patients; from refugees to prostitutes; and from gypsies to gangs and deviant youth behaviours. He also lectures across the social sciences and has published widely.

Contact: daniel.briggs@,universidadeuropea.es 